\section{BRITISH COLUMBIA}

The Faculty's extensive recruiting efforts are finally paying off with first-year enrollment hitting an all-time high and 214 new students entering the Faculty. The Natural Resources Conservation and Wood Products Processing programs both exceeded their first-year enrollment target by an amazing $28 \%$ and $62 \%$, respectively. The B.S.F and B.Sc. (Forestry) degree programs achieved $73 \%$ of their combined target. Undergraduate enrollment currently sits at 442 students, divided almost evenly amongst all four degree programs. The biggest challenge facing our undergraduate student enrollment has been the retention of new students beyond first year. To this end, we will be focussing maximum attention on ensuring that students currently enrolled in first year complete the year successfully and move into the second year of their program.

Dr. George Hoberg has been appointed as the research area leader for Policy and Institutional Analysis of the SFM Network. He hosted a Workshop entitled

\section{Ottawa Valley}

canopy walk. Autumn activities also include hunting for moose, deer, grouse, and hare. In the winter, snowmobiling and cross-country skiing are popular. The corporation plans to build cottages for yearround rental, winter being a very popular time, as the forest is on the snowmobile cross-country trail network. All these recreational activities are directly supportive of community interests.

At the center of the forest there is a visitor reception area. This comprises a restaurant, accommodation, nearby trails, and the forest canopy walk. The wet OVS visitors to the forest were warmed by a wonderful meal and the hospitality of Denis Côté of the Société Sylvicole and Louise Gagnon of the Corporation de la gestion de la Forét de l'Aigle. Many thanks to them for an educational and enjoyable day.
First Nations and Sustainable Forestry: Institutional Conditions for Success, October 23-24, 2003.

The Department of Forest Resources Management is delivering FRST 424, Sustainable Forest Management, the capstone 4th year integrated course, for the first time this term. In this modular, full-term course, students will work with participating companies to develop both Forest Management and Business Plans.

Dr. Stephen Sheppard has been awarded sabbatical leave funding from the Sustainable Forest Management Network to liaise with other Network members across Canada on research issues and communications initiatives on social sustainability.

Dr. Robert Magai and Dr. Lee Wookey, a visiting professor in Computer Science presented a joint paper entitled "Designing and Implementing a Geospatial Data Warehouse in Enterprise Forestry" at the IUFRO conference on Information Interoperability and Organization for National and Global Forest Information Systems, on September 17, 2003. Theirs was a lead-in paper on the subject of Systems and Applications.

Three Wood Science faculty members have received research funding from the Canadian Forest Service to investigate issues associated with the Mountain Pine Beetle (MPB) infestation. Colette Breuil has received $\$ 325000$ for a project entitled "Fitness and pathogenicity of the fungi associated with the MPB and other secondary beetles in green attack." Frank Lam and Phil Evans have received $\$ 80000$ to investigate "Alternative wood products from stained MPB lumber."

Dr. Hans-Joachim Krause has joined the Centre for Advanced Wood Processing as a Visiting Fellow. Dr. Krause is a chemist from Christian-Albechts University (founded in 1665) in Kiel, Germany. Dr. Krause will spend seven months here developing adhesive systems derived from natural plant resins. Such systems have the potential to replace the synthetic oil-derived adhesives currently used by industry to manufacture wood composites.

\section{Dr. Sue Watts, R.P.F.} Office of the Dean Faculty of Forestry Tony Bull

\section{TORONTO}

\section{Master of International Trade in Forest Products}

The Faculty of Forestry, University of Toronto, in cooperation with the Faculty of Law, the Rotman School of Management and the Institute of Policy Analysis, will launch a new Master of International Trade in Forest Products program in February, 2004.

Canada is built on trade and, amongst major forest-product-producing countries, is exceptional in its dependence on forest product exports, which are responsible for over 12 per cent of national export income. As the excruciating softwood lumber negotiations with the United States have demonstrated, this dependence also leaves the forest products industry and the national economy very vulnerable to any regulatory measures, treaties or restrictive practices that interfere with the free international movement of forest products. Such practices are of immense importance to Canada which, as a dominant producer, can and should, be a leader in promoting free, equitable trading relationships based on environmentally sustainable forest management practices

The Canadian international forest product trade has been overwhelmingly dominated by bilateral relationships with the United States, but it is increasingly influenced by a wide range of multilateral factors. These include development of international financial institutions, international currency markets and exchange rates, emerging major freetrade areas and associations such as the European Union and NAFTA, and global trade initiatives, such as the World Trade Organization. Environmental concerns, focussed by UNCED in Rio de Janeiro in 1992, and reinforced by last year's Earth Summit in Johannesburg, are increasingly influential and have emerged as central issues in international trade as potential non-tariff trade barriers and as objectives for global stewardship. Cultural issues, such as aboriginal land tenure and the ownership rights of indigenous peoples to genetic resources, are also increasingly important influences on international trade.

The interaction of all these factors provides an extremely complex and rapidly changing decision-making environment for governments at all levels involved 
in forest policy administration and for forest product companies that trade internationally. Comprehensive understanding of the factors that affect trade and capacity to predict future trends are clearly essential for industrial planning and policy development. Highly trained trade experts are as necessary to a vibrant forest sector as foresters to manage woodland operations and innovative wood product engineers. All forest product trading countries will need appropriate analytical expertise to guide government policy development, to predict economic and social impacts and to inform trade negotiations. Forest products industries and financial institutions will require similar expertise to guide tactical and strategic management and investment decisions.

Experts who can contribute effectively to international forest products trade must be exposed to ideas from many disciplines, including economics, business, law, forestry, forest product development and environmental sciences. They also must be exposed to practical experience drawn from long involvement in trade negotiations. At present there is no professionally focussed university program that combines all these elements. We believe that this is a gap of critical importance.

The new program is designed to produce a cadre of highly qualified and exceptionally competent specialists who can add major value to the international trade activities of their organizations. The program will be rigorous and highly selective, accepting only students who combine high academic qualifications with significant relevant practical experience. It is based conceptually on the Executive M.B.A. model and it is expected that most participants will hold and retain appropriate, relevant positions throughout the program.

The program will consist of six intensive, week-long modules, separated by periods of two to three months, for a total program duration of 16 months.

\footnotetext{
Module 1: Forest Policy and Management Analysis of forest policies, the effect of international conventions, regulations and standards on forest policies, different certification systems and their relation to sustainable forest management and forest products trade.
}

Module 2: Natural Resource Economics Forest products supply and demand, intertemporal resource allocation, market and non-market valuation mechanisms, stumpage and timber auction systems, product differentiation and price discrimination.

\section{Module 3 International Trade:}

Global and regional forest products markets, market equilibrium and benefits of trade, factors driving forest products trade and foreign direct investments

\section{Module 4 International Finance:}

Determination of exchange rates, choice of exchange rate policy, effects on forest products trade; the role of currency futures, options and swaps in the forest product s trade

\section{Module 5 International Trade Policy and Law:}

National and international trade policies, trade laws, conventions and institutions and their effects on forest products trade.

\section{Module 6 Case Studies in Forest Products Trade:}

In-depth analysis of selected case studies; topics could include, for example, incidents of trade obstruction and contributing policies and laws, the effect of emerging value-added product innovations on trade and markets.

Each module will involve a variety of instructional methods, including lectures, seminars, debates, and group project work. Each will include core instructors from each of the participating faculties, but a key feature of the program will be the active participation of an international panel of experts from Canada, the United States, Sweden, Finland, China, Switzerland and Australia. These include: Dr. Clark Binkley (Hancock Timber Resource Group)

Dr. Neil Byron (Australian Productivity Commission)

Dr. Allen Chan (Sino-Forest Corporation) Mr. Bob Carman (GPC International)

Mr. Fredrik Daveby (Lansforsakring Kronoborg)

Dr. Chris Elliott (WWF International)

Mr. Jim Farrell (Canadian Forest Service)

Mr. Michael Fullerton (Canadian Forest

Service)

Mr. Carl Grenier (Free Trade Lumber Council)

Mr. Timo Heikka (Stora Enso)

Dr. Jagmohan Maini (Consultant)

Ms. Katherine McGuire (Ontario Ministry of Opportunity, Enterprise and Innovation) Dr. Sten Nilsson (International Institute for Advanced Systems Analysis) Hon. Bob Rae (Goodmans LLP)

Mr. Adrian Whiteman (FAO)

The program will be coordinated by Dr. Susanna Laaksonen-Craig who specialized in forest economics and international trade at the University of Helsinki and University of California, Berkeley, and was an Assistant Director at the University of California Forest Products Laboratory.

The Faculty of Forestry is now accepting applications for the program. Further information may be obtained by visiting the Faculty's web-site at www.forestry. utoronto.ca, or by contacting Ms. Deborah Paes at 416-946-7952 or deborah.paes@utoronto.ca

\section{CIF/IFC MASTERCARD}

The Canadian Institute of Forestry/Institut forestier du Canada (CIF/IFC) is pleased to be working with MBNA to offer a $\mathrm{CIF} / \mathrm{IFC}$ Mastercard to their members. Every time you use the card, you will raise the profile of CIF/IFC and their members as the "voice of forest practitioners" and it will also provide benefits to the Institute to further CIF/IFC programs. For more information or to apply today please call 1-800-416-6345. 


\section{World Forestry Congress-Student and Faculty Perspectives}

Chris Gruenwald, University of New Brunswick

My experience at the 2003 World Forestry Congress was a great on so many different levels. As a UNB forestry student who hails from British Columbia, I had never been to Quebec City before. After spending six days there, I can say that it is the most beautiful city I have ever been to. The history and culture are truly unique in North America, and the warmth of the people is amazing. What a place!

We arrived to register at the Congress Center on September 20th and found ourselves right in the middle of a protest. A group of students from Quebec were protesting outside the Conference Center, and were very boisterous. I walked around the demonstration and talked to a few individuals. It seemed they were concerned about two things. The first was that they thought the congress was meeting to specifically discuss and decide Quebec forest policy, which I assured them was not the case. The second was that they wanted to participate in the congress and felt that the $\$ 750$ registration fee was excessive. I explained to some of them that the student registration was $\$ 150$, and if that was too expensive, they could attend the youth side event on Sunday, which was free. I was pleased to see that some did attend on Sunday, and I had some good discussions with them. As a forester, I feel that we need to do a much better job of both talking and listening to the public. Such a dialogue helps to create an understanding on both sides, and will help foresters to become better stewards of a public resource. Recent history has shown that conflict and mistrust from the public towards forestry started partially as a result of foresters who thought they had all the answers needed to manage the forest.

The Youth Side Event at the Hilton on Sunday was the first event I attended. There I met individuals from Germany, Australia, Africa, and Mexico. It was a great event, and reconfirmed to me that individuals hold many different values for forests. The challenges and opportunities of managing for such a diverse suite of values is what I most enjoy about being a forester.

I also attended a side event on Russian forests, which was very informative. I was particularly impressed with one Russian forester, who gave an honest, no-nonsense assessment of the forest management problems they are experiencing there. In North America, we often hear of the problems that Russia is having in making the transition to a market-based economy, and how corruption rules the day. But to hear it directly from a Russian government official was phenomenal. Another thing that stuck with me was that some of their forest management problems are similar to ones we have in Canada. More specifically, a big topic of discussion among the Russians was how to establish a mechanism to ensure that stumpage prices are fair. More than one commented on the fact that they felt stumpage prices were too low; this is a topic that I am quite familiar with, being from $\mathrm{BC}$.

On Monday, I attended a side event put on by the David Suzuki Foundation, entitled "Clearcutting in Canada's ancient rain forest." I was expecting some lively and spirited discussion, but was surprised at the amount of civility and respect there was among the presenters and those that attended. At this event, I was able to share my experiences and observations on the problems with "Ecosystem-based management," and I was able to question the presenters on how they would solve some of these problems. This was followed up on Tuesday, when I attended a presentation by the British Columbia government on its approach to forest management. At this event, I was able to share with the chief forester some of my concerns about forest management in BC, and ask if the government had plans to address them. I was appreciative of the fact that he gave me an honest and straightforward answer, without patronizing me. What I took from these events was that there were things from both presentations that I agreed and disagreed with. This served as a reminder to me that foresters should not align themselves with any particular group or interest; rather we should stand apart as a separate entity and take a leadership role in the management of Canada's forests. Only then will the Canadian public have confidence that we are managing the forest in their best interest.

On Wednesday I attended an event on the problems plaguing forestry research in Africa. Again many of the problems were similar to what we face in Canada. For example, a big problem for African researchers is being able to bridge the gap between research and forest management. In Canada, this problem is what Dr. Gordon Baskerville aptly describes as "Reading Gaelic Poetry to Deaf Seagulls," and it was interesting to see that we are not the only ones struggling with this issue.

On Thursday, I worked at the CIF booth, where I got to meet many people from all over the world. I particularly remember meeting and talking with the chief foresters from Turkey and Trinidad/Tobago. The chief forester of Trinidad/Tobago was a former UNB forestry student who came to Canada in 1972, and he shared with me the great experiences he had in the Maritimes as a student.

To conclude, I am extremely grateful to the CIF for sponsoring me so I could attend the 2003 World Forestry Congress. I would especially like to thank Roxanne Comeau and Doug Prosser for all the help they provided to me in completing an application for funding. This experience is one I will always remember fondly, and I look forward to attending future World Forestry Congresses.

\section{Morgan Kennah, University of British Columbia}

When I volunteered to be the liaison between the UBC Forestry Undergraduates and the Canadian Institute of Forestry's Vancouver Section last winter, I can now (embarrassedly) admit I knew no more about the CIF than that they were responsible for the silver rings we receive when we graduate. When I was offered the opportunity to attend the XII World Forestry Congress, both through UBC with the help of Peter Marshall (Associate Dean), the CIF Vancouver Section with Mike Prueter (Chair) and Denise Allen (Treasurer) primarily, and finally CIF National and Roxanne Comeau, I was a little sceptical. Not only had I never attended a formal conference before, but also I wondered whether it would be worthwhile of my time. In retrospect, I wonder how I could have imagined the experience would not have been worthwhile, and to say I'm glad to have gone would be an understatement. 
For my first full day in Quebec City, I attended a Youth Side Event. Here, students from around the world congregated to listen to the perspectives of Canadian and global leaders on the importance of youth representation in the Congress, and the challenges we are to face as the leaders of tomorrow. As part of this event, students were encouraged to participate in a working table discussion where we brainstormed on major issues for the lack of harmony between humans and the environment, suggesting reasoning, solutions and implementation techniques.

Once this day-long session was complete, I had an opportunity to further explore the Congress within the conference centre, attending the opening ceremonies and the launch of the exhibition hall. Two things stick out from memory of this day: translators and global diversity. Though I had read the Congress had three official languages (English, French and Spanish), I had not imagined how this might come into play throughout the week; unless you carried a translator around with you everyday, you were sure to be lost in at least one of the talks you would attend! Further, with exploring the opening of the exhibition, all preconceived thoughts of what I had expected to see there were surpassed. Not only were there booths representing countries, but also Canadian provinces, non-governmental organizations, environmental non-governmental organizations, certification systems, industry, and I am probably missing some categories. In between attending Plenary Sessions, Theme Sessions, and Side events, I found myself spending the majority of my time within the exhibition. This area provided the most opportunity for students to interact with individuals representing all different interests, allowing for networking and a chance to have some of our questions answered.

One key interest I had in attending the Congress, and thus swayed what sessions I chose to participate in, was what British Columbia had to present to the country and the world about our current state of the forests, and our recent policy changes. In addition to this, I was also very interested in what other organizations, primarily environmental non-governmental organizations, had to convey about BC forest practices. My expectations were met with what I expected to hear, both from the $\mathrm{BC}$ government perspective and from the environmental community. However, I can say I was definitely humbled with respect to how much I didn't know, both from a Canadian and global perspective. One of the most valuable perspectives I came out of the conference with was the realization of my limited and very focussed education gained from my undergraduate degree. Though I believe my education has been valuable, all previous conceptions I have held about the future of forestry were changed with my week spent in Quebec! Many students I interact with believe British Columbia is the end all, be all of forestry; I wish upon them to have an opportunity at some point to experience what other options await them outside of our province.

From a UBC perspective, I was given the opportunity to speak at a side event centred on students' perspectives about forestry and their associated schools. From an educational standpoint, this opportunity raised my awareness of what other Canadian schools offer for undergraduate degree programs, possibilities for graduate studies, and others' perceptions about forestry now, and in the future. I would like to thank the CIF and all those individuals that helped me

\section{LA CARTE MASTERCARD CIF/IFC}

Le Canadian Institute of Forestry / Institut forestier du Canada (CIF/IFC) a le plaisir d'annoncer la collaboration de MBNA dans le but d'offrir une carte Mastercard CIF/IFC à ses membres. Chaque fois que vous utilisez la carte, vous ferez en sorte d'accroître l'importance de l'Institut et de ses membres en tant que "porte-parole des praticiens de la foresterie" et vous permettrez à l'Institut de cumuler des bénéfices qui serviront à financer ses programmes. Pour de plus amples informations ou pour compléter une demande d'adhésion, veuillez composer le 1-800-416-6345, dès aujourd'hui.

\section{Assurances responsabilité professionnelle pour les membres de l'Institut en consultation}

La police d'assurances responsabilité professionnelle de l'Institut gérée par LMS Prolink Ltd Insurance Brokers vous fournira une protection de responsabilité légale en tant que tierce partie suite à une erreur reconnue, une erreur imputée, une omission ou un geste de négligence sous: Perte financière et vos coûts légaux.

Pour plus d'information, veuillez communiquer avec Rick Barnard, c.a., CAIB au 416-595-7484 ou au 1-800-663-6828, courriel: rickb@lms.ca. Pour un formulaire d'adhésion, veuillez communiquer avec le bureau national de l'Institut au tél.: 613-2342242, télécopieur: 613-234-6181, courriel:cif@cif-ifc.org

Police d'assurances groupe pour les membres de l'Institut forestier du Canada

L'Institut est heureux de fournir à ses membres un plan d'assurances groupe. Cette police est souscrite auprès de LMS Prolink. Elle offre:

- Assurance-vie et assurance décès et compensations en cas de perte de membre

- Compensation hebdomadaire pour perte de revenus

- Compensation pour incapacité à long terme

De plus, elle comprend une programme d'assurances pour les personnes à charge des membres:

- Programme d'aide aux membres "Connections"

- Assurance-santé étendue

- Assurance soins dentaires

Pour plus d'information, veuillez communiquer avec LMS Prolink Ltd. au 1-800-6636828, 416-595-7484, courriel info@lms.ca 
through organizing and financial aid that allowed me to attend the World Forestry Congress. I would hope to all those I met, we will stay in contact, and meet again; this experience was one of the most memorable of my undergraduate degree.

\section{Mihai Voicu, University of Alberta}

My name is Mihai Voicu. I am currently working on a Masters in Silviculture, at University of Alberta, Department of Renewable Resources. Between September 21 and September 28, I attended the XII World Forestry Congress in Quebec City, Canada.
First, I must say it was a tremendous experience to be part of such a big crowd (over 3500 people) of foresters, academics, students, landowners, etc. Besides the slightly different backgrounds of those people, it was very interesting to me to share knowledge and ideas with people from all over the world, and to get to know a bit more about the challenges some others face in their efforts towards sustainable forests. It seems to me that in those efforts a key factor could be interaction among governments, landowners, forest administrators, and local people. Having different perspectives on environmental

\section{CIF/IFC NATIONAL AWARDS}

\section{Nominate a colleague for one of CIF/IFC's national awards.}

The Canadian Institute of Forestry/Institut forestier du Canada recognizes through a national awards program the outstanding contributions made to Forestry by members and non-members.

\section{National Awards}

Canadian Forestry Achievement Award - recognizes outstanding achievement in forestry in Canada.

Canadian Forestry Scientific Achievement Award - recognizes outstanding achievement in forestry research in Canada.

International Forestry Achievement Award - recognizes outstanding achievement in international forestry.

James M. Kitz Award - recognizes the contributions of those newer to the profession.

Canadian Forest Management Group Achievement Award - recognizes outstanding achievement by teams and groups of Natural Resource managers, Researchers and NGO groups in the field of forest resources related activities in Canada.

Tree of Life Award - recognizes individuals who have made superior, dedicated or particularly effective contributions to sustainable forest resource management, forest renewal or sustained yield integrated management of the forest and its intrinsic resources.

\section{Nomination deadline for 2004 CIF/IFC National Awards is May 1, 2004}

Award criteria and nomination information may be obtained from the CIF/IFC web site - http://www.cif-ifc.org, CIF/IFC's national office 151 Slater Street, Suite 606, Ottawa, Ontario K1P 5H3 problems at a global level could broaden one's knowledge, and give new interesting ideas on which factors should be paid more attention.

On the other hand, as a technical experience it was not at a terribly high level. Sometimes, I noticed in the verbal presentations a lack of statistics and/or inconsistency in presenting the results scientifically. Another thing that could have been interesting was a session organized/moderated by students. However, supporting students to participate in such an extraordinary event (as CIF/IFC did with quite a few students from all over Canada), gave us a tremendous opportunity to deepen our knowledge and open new perspectives on the forestry sector.

\section{Avery Dorland, Lakehead University}

After spending a full week in Quebec City at the World Forestry Congress I couldn't help but feel a bit disconnected sitting in my tiny graduate student space at Lakehead University when I returned. I came out of the Congress with a feeling that there are many challenges in forestry that are quite universal, and that the state of forests in Canada is something to be proud of.

There were obvious themes that arose from the congress, such as sustainable development and community empowerment, but there was one underlying theme that also stuck out for me, that theme being the general or public perception of forestry, when it operates on an industrial scale. Speakers from Russia, Estonia and Austria all pointed out problems that arose from a body that was either granted or granted itself the responsibility for forest land tenure but knew very little about the realities of managing such a resource. However, when forest use was put into the context of community control, such as a model forest, there seemed to be a general acceptance of forest practices. The question never seemed to be the practice but more the practitioner.

Other themes that I could not relate to included illegal logging, extreme consumption, disorganized land tenure and outrageous death and injury rates among forest workers. I felt a sense of pride that Canadian forests do not have these problems on a national scale. It put Canadian forest management into perspective; it seems that we are doing a very good job of managing our resource if the problems that top our forest management 
arguments are guideline implementation and habitat protection.

The Congress left me with the impression that Canadians have a lot to be proud of about the way their forests are managed. However, I also left with the feeling that sustainable forest management on a global scale is more about politics than it is about science.

Michael Hoepting, Lakehead University

I am a Master of Science in Forestry graduate student at Lakehead University in Thunder Bay, Ontario. I attended the XII World Forestry Congress held in Quebec City in September. The main purpose of my participation in the Congress was to present a poster detailing my thesis work. However, the World Forestry Congress surpassed all expectations. Including delegates from all over the world and the theme being very global in scope ensured that it would be a relevant and professionally rewarding experience. As this was the first World Forestry Congress to be hosted in North America, the opportunity to be involved was accessible as well as memorable, since it is unlikely that I will attend others until the event returns.

The Congress held something for everyone. Theme sessions covered a variety of topics from climate change, to aboriginal rights, to biodiversity, to community forestry, to agroforestry, and everything in between. The numerous side events provided opportunities for delegates to explore and learn about issues and ongoing projects in a more in-depth and interactive forum. The exhibition contained not only amazing displays, but also knowledgeable, friendly representatives to answer questions and distribute the reams of pamphlets and promotional materials. Hosting the World Forestry Congress in Quebec City was also a great opportunity to showcase the progress we have made and the advancements underway in the often-scrutinized Canadian forest industry. Perhaps one of the most significant aspects of the Congress was to observe many attendees, and myself included, meet up with old classmates, colleagues, and friends, and also for the endless possibility of making new friends. In the end, the XII World Forestry Congress was a great success and fantastic experience.
David Balsillie Ph.D., Associate Professor, Sustainable Forest Management and Certification Faculty of Forestry, University of Toronto

On behalf of Shashi Kant, Andy Kenney, Ian Kennedy and the many students who assisted the Faculty of Forestry in its successful trip to the World Congress, I felt it would be informative to give everyone a report on the degree and extent of the Faculty's involvement at the Congress.

First, we wish to acknowledge the support of our sponsors: the Ontario Forest Industries Association, the Ontario
Lumber Manufacturers' Association, the Canadian Institute of Forestry, the World Forestry Congress, and the Office of Student Affairs at the University of Toronto.

Collectively these sponsors provided $\$ 14000.00$ to cover the cost of transportation and accommodation for our attendees. Without this level of support, our participation would have been severely curtailed. There is often considerable "talk" about the need for the involvement of youth in the business of forestry, but these organizations spoke clearly with their

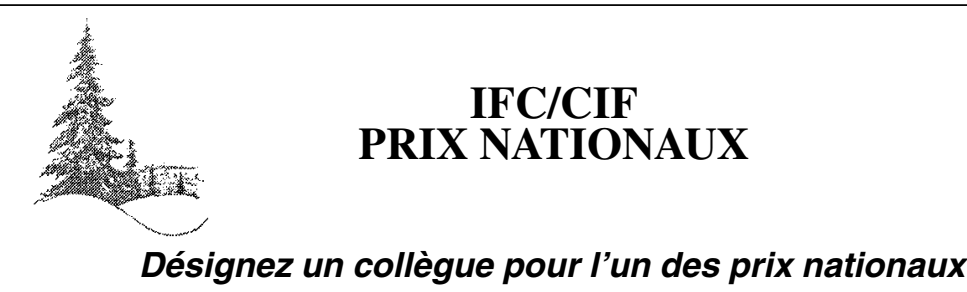

L'Institut souligne par ce programme de prix nationaux les réalisations remarquables en foresterie effectuées par les membres et nonmembres

\section{Prix Nationaux}

Prix pour une réalisation exceptionelle en foresterie au Canada - reconnaissance d'une contribution remarquable en foresterie au Canada.

Prix pour une réalisation exceptionelle en recherche forestière au Canada - reconnaissance d'une contribution remarquable en recherche forestière au Canada.

Prix pour une realisation exceptionelle en foresterie internationale reconnaissance d'une contribution remarquable en foresterie internationale.

Prix James M. Kitz - pour souligner les contributions des nouveaux venus en foresterie.

Prix d'excellence pour un groupe en aménagement forestier au Canada - reconnaître une réalisation exceptionnelle entreprise par des équipes et des groupes de gestionnaires des ressources naturelles, des chercheurs et des regroupements d'organismes non-gouvernementaux actifs dans le domaine des activités reliées aux ressources naturelles au Canada.

Prix de l'arbre de la vie - reconnaître les individus qui se sont dédiés, ou qui ont contribué de façon notable,ou de manière particulièrement efficace en aménagement durable des ressources forestières, en régénération forestière ou en aménagement intégré à rendement durable de la forêt et de ses ressources intrinsèques.

La date limite pour les nominations de l'Institut pour 2004 est le $1^{\mathrm{er}}$ mai 2004.

Les critères et l'information sur les nominations peuvent être obtenus en consultant le site Internet du CIF/IFC, http://www.cif-ifc.org, le bureau national de l'Institut, 151 Slater, Bureau 606, Ottawa, Ontario K1P 5H3 
financial contributions. Their efforts are truly appreciated.

The following students attended the Congress:

From the Master of Forest Conservation Program: Ildiko Apavaloae, Martha Copestake, Sarah Lawson, Joanna Mackie, Virginia Mersereau, Sarah Jane Miller, Melanie Plett, Mary Van Sleeuwen, Liat Podolsky, Pedro Lara Almuedo, Hadley Archer, Michael Bendzsak, James Hodson, Slawko Medwidsky, Jeff Biggs, Bedarul Alum, Christine Pansino, and Maia Becker.

From the Master of Science in Forestry Program: Patrick James, Peter Wood, Cassia Baten, and Susan Lee.

From the Ph.D. Program: Ingrid Aguayo, Jason Jabbour, Mark Robson, Kevin Kim, Tomasz Gradowski, Yang Feng'e, Julie Casimirri, Martin Kijazi, Sushil Kumar, and Dinesh Misra. We were also joined by two additional Ph.D. students who attended with the support of their home institutions: Peggy Smith (Lakehead University) and Gord Miller (Environmental Commissioner of Ontario).

Also attending were: Emma Lehrer (from the Bachelor of Science in Forest Conservation program), Christina Polzot (York University), Sarah Barkley (International Development Studies, Scarborough) and several students, Yvonne Eder, Sofia Barragan, Lukas Giessen, Manuela Hugger, and Silke Selchow, from our sister Faculty at the University of Freiburg, Germany.

The German students attended the Congress following their participation in our joint field camp at Haliburton Forest. They are proceeding to internship locations across Canada for several weeks before returning to Germany.

In addition, there were several graduates from the Master of Forest Conservation Program who actively participated in the proceedings of the Congress through paper and poster presentations, presentations and involvement in side events, and talking with Congress Delegates while stationed at their respective display booths. They included: Nick Moss-Gillespie (Soils Association, Woodmark), Christy Arseneau and Marian Chiu (Canadian Forest Service, Forest 2020 Program), Vivian Peachey (Forest Stewardship Council, Canada), Denise Allen (Ph.D. student at the University of British Columbia and partner in the consulting company Chrysalis Forestry), Evan Stew- art (Forest Stewardship Council, British Columbia and partner in the consulting company Chrysalis Forestry), Richard Brooks (Greenpeace), Scott Jackson (Ontario Forest Industries Association), Atrid Nielsen (Dendron Forestry), Linda Dwyer (Kitigan Zibi First Nation), Sadia Butt (Institute of Environmental Studies, U. of T.), and Riki Burkhardt and Kristy Faccer (Federation of Ontario Naturalists). Andy Park, a recent Ph.D. graduate, now involved in a post-doctoral position at the University of Quebec in Montreal, was also present.

Faculty staff who attended included: Dean Rorke Bryan, Susanna Laaksonen-Craig, Shashi Kant and me.

Along with the activities listed below, the Dean, Susanna, Shashi and I had the opportunity to discuss our newly approved Master of International Trade in Forest Products with numerous potential supporters, speakers and participants in this exciting development.

Oral Papers presented by Faculty of Forestry staff, students or recent graduates:

Meaningful consultation with indigenous peoples in forest management: a focus on Canada, Monique Ross and Peggy Smith (presented by Peggy Smith).

Community-based forest management in bureaucratic organizations: are they compatible? Sushil Kumar and Shashi Kant (presented by Sushil Kumar).

Economic theory of emerging forest property rights, Shashi Kant.

Production functions for multiple outputs of joint forest management, Dinesh Misra and Shashi Kant (presented by Dinesh Misra).
Abstracts that were included in the Congress Proceedings, but not orally presented:

A multi-dimensional framework and its application to aboriginal co-management arrangements in the forest sector of Canada, Jennifer Shuter and Shashi Kant (Jennifer Shuter is a recent Master of Forest Conservation graduate).

The application of choice modelling in developing sustainable forest policy: a potential instrument for analysing and integrating social values, Jason Jabbour, David Balsillie and Shashi Kant.

Boreal forest fires: an increasing issue in a changing climate, B. D. Amiro, M. D. Flannigan, B. J. Stocks, J. B. Todd and B. M. Wotton (Mike Wotton is a Ph.D. candidate at the Faculty of Forestry).

Ecological evidence for sustainability of logging in the tropics, Jane Okalebo (Jane is an MScF candidate at the Faculty of Forestry)

Urban forestry trends in Canada, M. R. Rosen and W. A. Kenney (Andy Kenney is a Senior Lecturer at the Faculty of Forestry)

Problems with integrating traditional ecological knowledge into contemporary resource management, Julie Casimirri.

Forest management institutions and the implimentation of criteria and indicators of sustainable forest management, Martin Kijazi and Shashi Kant.

Poster presentations by Faculty staff, students and recent graduates:

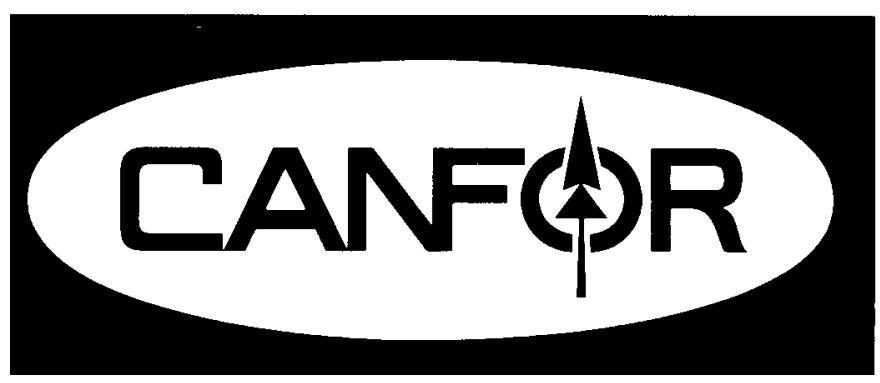

A CIF/IFC Corporate Sustaining Member 
Canadian Council of Forest Ministers, Forest 2020: The next evolution of Canadian Forestry, Marian Chiu.

Modelling contextual influences on participatory decision-making for sustainable forest management, Mark Robson and Shashi Kant.

Field testing FSC principles and criteria in a Mexican ejido, Nick Moss-Gillespie and Andy Park.

Changing forest values of southern Ontario: Large-scale clearcutting to conservation, Sadia Butt and A. French.

Impacts of soil amendments on canopy physiological processes in tolerant hardwood stands, Tomasz Gradowski and Sean Thomas.

Public policy affecting afforestation and deforestation in southern Ontario, Gord Miller and David Balsillie.

Professor Susanna Laaksonen-Craig had a poster entitled "Foreign Direct Investments in the Forest Sector" and Sarah Lawson (MFC student) was one of a number of students from around the world who were showcased in the Youth Exhibit in the Exhibition Hall.

Participation by Faculty staff, students and recent graduates in the Congress side events:

Peggy Smith and Linda Dwyer: Indigenous Peoples' Forest Forum; September 19-21.

Peggy Smith and Vivian Peachey: FSC: Forest Voices, Common Choices; September 21.

Multiple Students: Youth Side Event: What should we do with our forests? Think, talk and take action; September 21 .

Jason Jabbour, speaker on behalf of the International Forestry Student Association: CIF Side-event; A World of Forest Practitioners; September 21.

Dean Rorke Bryan, Jason Jabbour, and Jeff Biggs: speakers at the Association of Forestry Schools of Canada Sideevent: Forestry Education in Canada; September 25.
Maia Becker: spoke about the Envirothon Program for Young People at the Canada Hour in the Exhibition Hall, on September 22.

Through their presence and asking questions at oral presentations and side events, discussions with presenters at the poster sessions, talking to various representatives at the displays in the Exhibition Hall, and talking to Congress Delegates in the Hallways, the involvement of the Faculty delegation was evident throughout the week.

Finally, one of our students, Jason Jabbour was asked to read the "Final
Statement" of the Congress at the Closing Ceremonies. There was great pride amongst the $\mathrm{U}$. of $\mathrm{T}$. group as Jason was introduced to present this document to the Congress Delegates from around the world. Jason did an excellent job and was a great ambassador for our Faculty, IFSA and Canada.

From Sunday to Sunday, the Faculty of Forestry delegates made their presence felt. Many new contacts were made and relationships were developed. This will be an event that will remain in the students' memories for many years to come.

\section{Errors and Omissions Insurance for CIF/IFC Consultant Members}

CIF/IFC Errors \& Omissions policy administered by LMS Prolink Ltd. Insurance Brokers will provide you with coverage for third party legal liability resulting from an actual or alleged error, omission, or negligent act for: Financial Loss and your Legal Costs.

For more information: please contact Rick Barnard C.A., CAIB at 416-5957484 or 1-800-663-6828, email: rickb@lms.ca. For an application form, please contact the CIF/IFC National Office at Tel : 613-234-2242, Fax: 613-234-6181, Email: cif@cif-ifc.org

Group Benefits plan for CIF/IFC Members:

CIF/IFC is pleased to provide a group benefits plan to their members. The plan is underwritten by LMS Prolink Ltd. It offers:

- Life Insurance and Accidental Death and Dismemberment Benefits

- Weekly Income Benefit

- Long Term Disability Benefit

As well as optional Member Dependent Benefits:

- Member Assistance Program "Connections"

- Extended Health Care

- Dental

For more information, please contact LMS Prolink Ltd. 1-800-663-6828, 416-595-7484, email info@lms.ca 